\title{
Periodontal Infectogenomics
}

\author{
Gurjeet Kaur, Vishakha Grover, Nandini Bhaskar, Rose Kanwaljeet Kaur and Ashish Jain*
}

\begin{abstract}
Periodontal diseases are chronic infectious disease in which the pathogenic bacteria initiate the host immune response leading to the destruction of tooth supporting tissue and eventually result in the tooth loss. It has multifactorial etiological factors including local, systemic, environmental and genetic factors. The effect of genetic factors on periodontal disease is already under extensive research and has explained the role of polymorphisms of immune mediators affecting disease response. The role genetic factors in pathogens colonisation is emerged as a new field of research as "infectogenomics". It is a rapidly evolving and high-priority research area now days. It further elaborates the role of genetic factors in disease pathogenesis and help in the treatment, control and early prevention of infection. The aim of this review is to summarise the contemporary evidence available in the field of periodontal infectogenomics to draw some valuable conclusions to further elaborate its role in disease pathogenesis and its application in the clinical practice. This will open up opportunity for more extensive research in this field.
\end{abstract}

Keywords: Infectogenomics, Genetics, Microbes, Periodontitis, Bacterial species, Invasion, Proliferation

\section{Background}

Periodontal disease is a highly prevalent, multifactorial, chronic inflammatory disease of periodontium eventually leading to destruction of supportive tissues of teeth and tooth loss. The interaction between microbes present in dental plaque and host immune response is a major determinant of progression and clinical manifestations of periodontal disease $[1,2]$. However, there are multitude of factors like systemic, environmental and genetic which directly or indirectly influence this association at multiple levels [3, 4]. It has been seen that individuals harbouring almost equivalent local etiological factors could represent the diverse disease severity. These observations lead to the idea of some unrecognised components of the host genetic constitution or the environment which was responsible for differences in their susceptibility of disease $[5,6]$. The disease susceptibility is determined by immune response of the body as applies to periodontal disease, which is largely determined by genetic or epigenetic factors $[6,7]$. The effects of these factors have been extensively studied over the last 20 years using different study designs. This has resulted in a significant paradigm shift in the aetiology of periodontal disease with the increased emphasis on host and its genetic constitution as modifiers of the bacterially

\footnotetext{
* Correspondence: ashish@justice.com

Department of Periodontology, Dr Harvansh Singh Judge Institute of Dental Sciences and Hospital, Panjab University, Sector-25, Chandigarh, India
}

induced disease and for increased risk of disease occurrence and severity.

A huge published literature is available regarding genetic analysis using candidate gene and human leukocyte antigen (HLA) markers for periodontitis among which the polymorphism studies of genes coding for cytokines have received the most attention [7]. Lot of investigations have been conducted to identify specific gene polymorphisms associated with risk for periodontal diseases. No specific single gene polymorphism could be defined, owing to polygenic nature of disease [6].

The altered immune response due to these gene polymorphisms affects the microbial composition present in periodontal environment. Humans are considered supraorganisms consisting of trillions of symbiotic, commensal and pathogenic bacteria [8, 9]. The oral cavity contains over 1000 different microorganisms including 700 different species with as many as 19,000 different bacterial phylotypes which are mostly commensal in nature $[3,8]$. A myriad of host factors is responsible for the development of composition of oral microbiome, its role in oral health and disease which further shows subject to subject variation $[8,10]$. Many polymorphisms affecting the immune response have been linked to periodontal disease which indirectly may have an impact on the quantity and quality of microbial colonisation [3].

(c) The Author(s). 2018 Open Access This article is distributed under the terms of the Creative Commons Attribution 4.0 International License (http://creativecommons.org/licenses/by/4.0/), which permits unrestricted use, distribution, and reproduction in any medium, provided you give appropriate credit to the original author(s) and the source, provide a link to the Creative Commons license, and indicate if changes were made. The Creative Commons Public Domain Dedication waiver (http://creativecommons.org/publicdomain/zero/1.0/) applies to the data made available in this article, unless otherwise stated. 
This has led to a novel concept in aetiology of periodontal disease i.e. "infectogenomics".

\section{The concept of infectogenomics}

Infectogenomics was first defined by Kellam and Weiss (2006) as the study of interaction between host genetic variations and colonisation by pathogenic microbes [11]. This term is in line with the word pharmacogenetics in which the appearance of a disease or symptom following exposure to an infectious agent can be regarded as an unusual side effect just like an adverse reaction to a drug [11]. With the alteration in the host genotype, these adverse reactions can be severe in one person as compared to the other.

The concept for infectogenomics states that the genetic defects in the recognition and response pathways of the host to identify microbial pathogens predispose to either altered microbial colonisation or misrecognition of normal microbiota leading to dysbiosis and appearance of infectious disease [9]. This hypothesis of association between host genomic adaptations and microbiome is well studied in many systemic disease conditions. A specific disease endemic to a particular population is known to cause certain genetic mutations as a result of this selective disease susceptibility and renders the population in subsequent generations resistant in due course of time. The classical example of this concept of selective pressure is studied in malaria endemic areas where the modifications in the human haemoglobin genes make this population resistant to malaria $[12,13]$. Such mechanisms strongly support the concept of genetics linking disease susceptibility. Converse to this the concept of infectogenomics which suggests the reverse relationship that certain genetic constitutions are particularly susceptible to the disease and this is mediated by the selective pressure in terms of microbial colonisation or proliferation $[3,14,15]$.

The genomic adaptations of the host can have effect either on the pathogen invasion or on pathogen proliferation $[3,9]$. After the invasion of pathogens in the human body, the interaction between the pattern recognition receptors (PRRs) and the pathogen associated molecular patterns (PAMPs) generate cellular signalling against microbes. Any mutation or modifications in the PRR genes may thus result in either its altered expression or affect its ability to recognise microbial constituents effecting invasion of pathogens in the host [9]. A well documented association is between the CCR5$\Delta 32$ deletion allele and human immunodeficiency virus (HIV) resistance. CCR5 chemokine receptor is used by HIV strains to gain entry into immune system cells. So, CCR5- $\Delta 32$ deletion allele provided almost complete resistance against HIV-1 in homozygous state and partial resistance with slower disease progression in heterozygous state [16-18]. It was hypothesised that this modification in the genetic constitution arose in high risk population due to selective pressure from bubonic plague or small pox [17]. Next step in the pathogenesis is the proliferation of the pathogens that trigger immune-pathological reactions which determines the severity and progression of infectious disease. Inflammation being a central mechanism in many chronic human diseases, any alteration in immune regulatory genes may affect the disease pathogenesis. Selective genetic variations may result in skewing the microbial composition toward more pathological microbes or alters the host response for developing resistance for a particular pathogen [9]. This mechanism is well documented as conferring resistance to malaria in subjects with haemoglobin $\mathrm{S}(\mathrm{HbS})$ variant in malaria endemic population [12, 13]. In the individuals presenting with $\mathrm{HbS}$ homozygous traits the presence of Plasmodium falciparum causes the red cells to rupture, thus inhibits its proliferation or colonisation [19]. Converse to this is a well studied association between the cystic fibrosis and Pseudomonas aeruginosa infection in which the $\Delta \mathrm{F} 508$ mutation in cystic fibrosis transmembrane conductance regulator (CFTR) gene lead to hypersusceptibility to chronic lung infection due to alterations in $\mathrm{pH}$, ion concentrations and formation of dehydrated airway surface layer which contributes to increased proliferation of Pseudomonas aeruginosa $[20,21]$. Other examples are protective role of Thelper cells type 2 (Th2) immune responses against Schistosomiasis [12], polygenic susceptibility to tuberculosis [22] and protection against chronic viral hepatitis [23]. However, in case of extensively studied inflammatory bowel disease the genetic mutations have affect on both the pathogen invasion and proliferation; explains the bidirectional relationship of the microbiome interactions with host genetics as between altered host immune function and altered bacterial community functions, features or by-products $[15,24]$. So, these medical evidences provide us with some clear patterns of associations emerging in the field of infectogenomics.

\section{Periodontal infectogenomics}

With the advancement in the research it has been seen that the most prevalent chronic periodontitis being multifactorial also entails a dysbiotic oral microbial shift and a deregulated host inflammatory response resulting in progressive periodontal tissue destruction $[10,25]$. Earlier the main focus for the genetic analyses was the association of periodontal disease with altered immune response taking into consideration some candidate genes related to immune pathways. In the past 15 years a lot of research work is mainly focused on this new concept of periodontal infectogenomics which will potentially help to better understand the pathogenesis of periodontal disease. 
Genetic factors affecting periodontal pathogen invasion In periodontal environment, microbes causing infection must have the ability to attach to the tissue surface, to multiply, to compete against other microbial species and to defend against host responses [3,9]. One of the key systems for immune surveillance is complement system which links the innate and the adaptive arms of the host immune response [26, 27]. In monogenic Ehler Danlos Syndrome the alterations in $\mathrm{C} 1 \mathrm{R}$ or $\mathrm{C} 1 \mathrm{~S}$ genes encoding for complement 1 subunits $\mathrm{C} 1 \mathrm{r}$ and $\mathrm{C} 1 \mathrm{~s}$ has been documented as a link between connective tissue pathology with classical complement pathway [28]. Integrative gene prioritisation method has listed C3 among the top 21 most promising candidate genes involved in periodontitis (Polygenic condition) [26, 29]. Animal model investigations have indicated that complement is involved in both the dysbiotic transformation and the inflammatory response that leads to destruction of periodontal tissue. Similar findings have been reported in human clinical and histological studies [26]. In Hong Kong Chinese population single nucleotide polymorphism of C5 (rs17611) with genotype AG and the haplotype CGCA containing rs1035029, rs17611, rs25681 and rs992670 has been found to be significantly more prevalent in periodontitis patients than in healthy controls [27, 30]. Only the MBL2 homozygote $(\mathrm{O} / \mathrm{O})$ variant type, a secreted pattern-recognition molecule in the cascade of lectin pathway, could provoke the virulence of $A$. actinomycetemcomitans with no difference found between $P$. gingivalis and/or inflammatory markers in saliva and periodontal tissue destruction in study subject [31].

The mutations in few pattern recognition receptors including toll like receptors (TLRs), NOD-like receptors (NLRs), formyl peptide recptors and Fc receptors have been studied so far to express the alteration or the misrecognition of microbial constituents resulting in altered response to microbes. The effect of genetic polymorphisms in these receptors is mainly expressed as their response characteristics at the protein and mRNA level after exposure to various cytokines and microbes. The CD14 -260CT + TT genotype is found to have higher frequencies of red complex bacteria i.e. Porphyromonas gingivalis, Treponema denticola and Tannerella forsythia particularly in renal transplant patients with cyclosporine $\mathrm{A}$ induced gingival overgrowth which is associated with high interleukin-1 $\beta$ (IL-1 $\beta$ ) levels [32]. The altered immune response due to immunosuppressive medication and disruption of normal symbiotic relation can be plausible explanation for these findings. In contrast, the CD14-159TT variant has found to have a protective role in periodontitis patients by reducing subgingival colonisation of Prevotella intermedia [33]. In the healthy individuals the mutant type of TLR 4 (Asp299Gly heterozygote) has been appeared less responsive to
Porphyromonas gingivalis than wild type TLR4(normal) [34]. But no association has been seen with TLR4 polymorphisms (Asp299Gly and Thr399Ile) in periodontitis patients in relation to subgingival occurrence of periodontopathogens [33]. Similarly, TLR 2 polymorphism ($16,934 \mathrm{~T} / \mathrm{A})$ in both healthy and periodontitis patients has shown no association [35]. In Czech population, the TLR-9 haplotype $-1486 \mathrm{~T} /-1237 \mathrm{~T} /+2848 \mathrm{~A}$ has been found to increase the susceptibility of chronic periodontitis but without affecting the subgingival colonisation of bacteria [35]. Another, extensively studied receptor is $F c$ receptors only in two alleles i.e. FcyRII and FcyRIII types. Fc $\gamma$ RIIa131H/H genotype has been found to be hyperreactive phenotype of the polymorphonuclear neutrophils (PMNs), which release more bioactive molecules in response to periodontal pathogens and aggravate the periodontal destruction $[36,37]$. In contrary to this the FcyRIIb-nt645 + 25AA genotype has been seen to be linked with more severe periodontitis in Japanese population, due to suppression of humoral response against periodontopathic $[38,39]$. Similarly, inefficient phagocytosis of bacteria by neutrophils in FcyRIIIb-NA2 subjects is responsible for an increased levels of bacteria in gingival crevice leading to high risk of periodontitis [40]. Most of the investigations were documented in chronic periodontitis, only a single polymorphism studied in relation to aggressive periodontitis is nt324 A/A FcoRI polymorphism. It exhibited similarly a decreased phagocytosis of periodontopathic bacteria Porphyromonas gingivalis in Japanese population [41]. This body of literature revealed that functional differences in the activity of immune cells possibly lead to inter individual differences in the subgingival colonisation of periodontal pathogens and the development of periodontitis.

\section{Genetic factors affecting periodontal pathogen proliferation/ clearance}

The recognition of invaded periodontopathogens leads to the activation of immune regulatory mechanisms which is deterministic for the onset and progression of periodontal disease. It was hypothesised that alteration in the genetic constitution of components of immune regulatory mechanism can alter the subgingival environment for the proliferation of microbes in both healthy and diseased state of periodontium.

\section{Chronic periodontitis}

The polymorphisms in the cluster of $I L-1$ gene have been the most extensively studied polymorphism as to explore the link of periodontal disease pathogenesis. Infact, a genetic susceptibility kit based on IL-1 $\beta$ polymorphisms has been commercialised. But apart from the direct effect on host defence mechanisms, indirect bearing of the polymorphisms on periodontal microbes also 
has been documented. The subjects with $\mathrm{IL}-1 \mathrm{~A}(+4845)$ and $\mathrm{IL}-1 \mathrm{~B}(+3954)$ genotype have exhibited higher mean counts of subgingival species belonging to red and orange complexes like Tannerella forsythia, Treponema denticola, Fusobacterium nucleatum subspecies, Fusobacterium periodonticum, Campylobacter gracilis, Campylobacter showae, Streptococcus constellatu, Streptococcus intermedius, Streptococcus gordonii and 3 Capnocytophaga species in sites with increasing pocket depth [42]. In contrast, the Caucasian subjects with this single nucleotide polymorphisms (SNPs) presenting periodontitis has demonstrated negative association with the subgingival colonisation of microbes [43-46]. But individually IL-1 $\beta+3954$ genotype had exhibited higher prevalence of Porphyromonas gingivalis, Tannerella forsythia and Treponema denticola species in subgingival sites and higher expression of IL-1 $\beta$ mRNA [47]. So, additively both can affect the potential outcome of periodontal disease. In a group of subjects with periodontitis with IL-1A-889 and IL-1B + 3953 genotype the total count of red complex (Porphyromonas gingivalis, Tannerella forsythia and Treponema denticola), orange complex (Fusobacterium nucleatum, Peptostreptococcus micros, Prevotella intermedia, Campylobacter rectus) bacteria and of Campylobacter rectus has been found to be 3-fold and 2-fold higher than the negative genotype subjects [48]. So, IL-1 genotype is considered as a nonmandatory but a contributable risk factor for periodontal disease progression and no definitive conclusions could be drawn on the effect of this genotype on the individual subject's overall mean bacterial load or of their colonisation by specific bacterial clusters. However, allelic forms of same gene polymorphism differentially affect the colonisation of same pathogens. As Caucasian individuals with $I L$ 2 -330,166 TT:TT genotype has presented with a positive association for the subgingival presence of Porphyromonas gingivalis and bacteria of the red complex, but individually subjects with interleukin-2166 TT genotype have been more oftenly infected with Porphyromonas gingivalis and bacteria of the red complex whereas a decreased occurrence of Porphyromonas gingivalis and bacteria of the red complex found in interleukin-2 -330 TG-positive subjects with a decrease in the odds ratio for chronic periodontitis (odds ratio $=0.394$ ) whereas IL2 $-166 \mathrm{TT}$ and haplotype IL-2 -330,166 TT:TT associated with an increase in odds ratio (odds ratio $=2.82$ or 2.97) [49]. Such kind of observations can pave pathway for the use of gene polymorphisms and their haplotype combination as a putative prognostic factors for chronic periodontitis. The level of periodontopathogens Porphyromonas gingivalis, Tannerella forsythia and Treponema denticola has been found to be higher in Caucasians with chronic periodontitis carrying $I L-4$ haplotype with Treponema denticola detected in higher counts at diseased sites [50]. This was attributed that the gene polymorphisms alter the immune response against pathogens either by promoting the proinflammatory cytokine production or by suppression of anti-inflammatory function. So, the alteration in a single gene can influence the various cytokines by altering dominated arm of immune response as seen for the levels of IL-4 and IL-13 which are influenced by IL-4 receptor complex specially the $I L-4 R A Q 551 R$ and associated with diseases such as the Hyper-IgE syndrome, Atopic dermatitis, Asthma, Systemic lupus erythematosus (SLE), Sjörgren syndrom, Systemic scleroderma, and Cutaneous mastocytosis, where an allergic or autoimmune pathogenesis is assumed [51]. At the same time, this alteration in the immune response have an impact on pathogen colonisation with $\mathrm{QR}+\mathrm{RR}$ polymorphism of IL-4RA Q551R found to be associated with increased presence of Tannerella forsythia in same population [52]. The polymorphism have either enhanced the signal transduction inducing a Th2 dominated response which was ineffective against periodontopathogens or decreased signal transduction with a dominated Th1 type of immune response [52]. So, the altered immune response could cause destructive disease even at lower bacterial loads via influencing response to bacteria rather than their counts. As analysed in the diseased sites of AGT/TTC patients of IL8 gene polymorphisms $-845 \mathrm{~T} / \mathrm{C},-738 \mathrm{~T} / \mathrm{C},-251 \mathrm{~A} / \mathrm{T},+396 \mathrm{~T} / \mathrm{G}$ and + 781C/T, a higher levels of Porphyromonas gingivalis, Tannerella forsythia, Treponema denticola and red complex have been detected as compared to the patients with ATC/TTC genotype presenting similar clinical parameters suggesting the more destructive inflammatory response even after a lower microbial challenge in patients with ATC/TTC genotype [53]. Similarly, the level of pathogens has been found to be higher in the patients without IL-8 haplotype than with the haplotype patients at the diseased site [54]. In Caucasian patients presenting IL- $8+781 C C$ genotype with chronic periodontitis the destructive frequency of Tannerella forsythia was much less explaining the more destructive immune response [55]. However, in relation to $I L-10$, a multifunctional anti inflammatory cytokine, the subjects positive for ACC, ATA and ACA/ ATA have been associated with decreased prevalence of Prevotella intermedia as compared to GCC/GCC positive subjects [56]. The genetic constitution was associated with low IL-10 production which is responsible for high local immune response against Prevotella intermedia implicated in severe periodontal tissue destruction [56]. Most of polymorphisms analysed in relation to chronic periodontitis have an impact mainly on pathogens belonging to red or orange complexes. However, a strong association has been seen with Aggregatibacter actinomycetemcomitans in IL-6 -174GG genotype subjects considering all subject and tooth related factors [57]. The periodontal pathogen colonisation was found to be unaffected by $I L-12$ genotype polymorphisms where as IFN- $\gamma 874$ AA carriers have been 
documented for decreased odds ratio for the presence of Aggregatibacter actinomycetemcomitans in the oral cavity. Moreover, IFN- $\gamma$ 874TA predisposed to infection with Prevotella intermedia in a group of Caucasian subjects presenting with all disease states [58]. IL-12 and IFN- $\gamma$ are known to bear a significant application as the maintenance of balance between the Th1 and Th2 type of immune responses. IFN- $\gamma 874$ AA genotype carriers primarily activate Th2 cells, as a low producer IFN- $\gamma$, only few Th1 cells are also activated, making a more pronounced humoral immune response more effective against Aggregatibacter actinomycetemcomitans. Conversely, in subjects who expressed the genotype IFN- $\gamma$ 874 TA, an intermediate IFN- $\gamma$ production was associated with an unbalanced Th1/Th2 immune response against Prevotella intermedia [58]. There was found to be negatively associated relationship of IFN- $\gamma$ polymorphisms with the periodontal pathogen colonisation in healthy and chronic periodontitis group in Czech population [59].

Many other cytokines gene polymorphisms like tumour necrosis factor- $\alpha$ (TNF- $\alpha$ ), HLA- II, nuclear factor kappa $\beta$ (NF-k $\beta$ ), Vitamin D receptor, T bet, MMP8, Apolipoprotein E, peroxisome proliferator activated receptor gamma (PPAR $\gamma$ ) involved in periodontal disease pathogenesis are also studied in context with periodontal infectogenomics. Only TNF- $\alpha$-308GG/-238GG haplotype showed more frequent presence of Prevotella intermedia in Caucasians [60]. Similar findings have been reported in coronary heart patients with severe periodontitis in carriers positive for AG + AA genotype and A-allele of TNF- $\alpha-308 G>$ A with a risk of 1.4 fold [61]. However, no differences have been found in the frequency or in the load of the periodontopathogens investigated in the different TNFA - 308 genotype groups [62]. The TBX21 -1993 T/C polymorphism of key transcription factor T-bet also found to be involved in the impact of Th1 responses but no association has been documented with load of red complex bacteria [63]. Similarly, no association with the subgingival occurrence of pathogens has been found for Taq1 polymorphisms of vitamin D receptor [64], MMP8 $-799 \mathrm{C} / \mathrm{T}$ and $+17 \mathrm{C} / \mathrm{G}$ variants [65], polymorphisms of Apolipoprotein E [66] and PPARyPro12Ala polymorphism [67]. To delineate further, more well designed and controlled studies are needed to explore the associations between microbes and host genetic constitution.

\section{Aggressive periodontitis}

The most extensively studied polymorphism is of $I L-6$ gene especially in subjects with aggressive periodontitis. IL-6 -174G genotype has been found to be associated with Aggregatibacter actinomycetemcomitans in generalised aggressive periodontitis patients and with both Aggregatibacter actinomycetemcomitans and Porphyromonas gingivalis in IL-6 -174GG and IL-6 -6106AA polymorphisms [68, 69]. A survey of Indian population on the IL-6 -174 polymorphism presented that in addition to Aggregatibacter actinomycetemcomitans another bacteria Capnocytophaga sputigena belonging to the green complex found in increased counts in periodontal pockets [70]. The haplotype $-174 \mathrm{G},-572$ C, $-1363 \mathrm{G},-1480 \mathrm{C}$, and -6106 A alleles have been reported to be associated with higher detection of Aggregatibacter actinomycetemcomitans whereas haplotype - 174 C, - 572 C, - 1363 T, - 1480 G, and - 6106 A alleles have supposedly protective function toward Aggregatibacter actinomycetemcomitans colonisation [69]. So, these findings to some extent confirm the hypothesis that complex interactions between the microbiota and host genome can affect the susceptibility to aggressive periodontitis. Such strong association can be explained as mainly due to faster hyperinflammatory immune response and stimulation of the overgrowth of some particular component of opportunistic organisms making the IL-6 hyperproducer individuals prone to increased risk for periodontal tissue destruction. A rare group of Caucasian population with $I L-1 \alpha$ rs1800587, $I L-1 \beta$ rs1143634 genotype and composite genotype (rs1800587_rs1143634), a significant association of genetic variants and the twofold higher risk of subgingival occurrence of Aggregatibacter actinomycetemcomitans have been proved [71]. Further, IL-8 -251TT genotype subjects also presented with the increased odds ratio for presence of Aggregatibacter actinomycetemcomitans in same population [55]. However, longitudinal investigations failed to confirm the role of this host- bacterium interplay in pathogenesis of aggressive periodontitis and its relation to IL- 1 composite genotype [72]. In Japanese population, the gene polymorphisms of more frequent $5^{\prime}$ flanking region of IL12RB2 has been associated with higher serum IgG titres against periodontal bacteria Aggregatibacter actinomycetemcomitans, Capnocytophaga ochracea, Eikenella corrodens, Fusobacterium nucliatum [73]. This explained the skewing of immune response toward Th2 responses with higher production of immunoglobulins after infection with periodontal bacteria in carrier group. Major histocompatibility complex-II (MHC-II) gene polymorphisms in same population presented with a suggestive hypothesis that the determination of the location of atypical BamHI restriction site in the HLA-DQB1 gene might be useful for determining a tendency toward high susceptibility to localised aggressive periodontitis with Tannerella Forsythia infection [74]. The $N F-\kappa \beta-94 \mathrm{del} / \mathrm{del}$ genotype has also presented with positive association to aggressive periodontitis and with the subgingival occurrence of Aggregatibacter actinomycetemcomitans in Caucasians [75].

\section{In response to Periodonatal therapy}

In Caucasian subjects with IL-1A + 4845/ IL-1B-3954 genotype undergoing supportive periodontal therapy, it 
has been suggested that a lower bacterial load is required in IL-1 gene positive subjects to develop the same level of periodontitis as in IL-1 gene-negative subjects as analysed from the bacterial load at different sites [76]. However, the periodontal therapy has been found to be equally effective and efficient to reduce the counts of periodontopathogens irrespective of their genetic background [50]. Therefore, the response to periodontal therapy has been found independent of the genetic profile of individual.

\section{Other periodontal conditions}

In order to study the impact of the genetic constitution on implants, a retrospective study in subjects with IL- $1 \alpha$ -889 and IL-1 $\beta+3953$ polymorphisms has been reported to be associated with higher implant loss in synergism with the smoking but without any alteration in microbial colonisation [77].

Among the rare conditions, the IL-10 SNPs has been analysed in renal transplant patients with cyclosporine-A induced gingival overgrowth in a Chinese population and found to be associated with the higher prevalence of Porphyromonas gingivalis and Treponema denticola especially in subjects with ATA haplotype [78]. So, the low IL-10 expression amplifies the local inflammatory response contributing to development of gingival overgrowth which favours the overgrowth of periodontal pathogens mainly Porphyromonas gingivalis and Treponema denticola.

A hypothesis has been made to explain the role of infectogenomics in perio- systemic relationship mainly in type 2 diabetes mellitus in association with IL-1 genotype polymorphisms and suggested that dental plaque remains the major contributory factor to progressive periodontitis with periodontal interleukin-1 gene polymorphisms and differences in oral microbiota seem to play only a subordinate role [79].

Through the discrete result from all the studies are difficult to be drawn and the mechanisms yet to explain further. However, the possible biological explanations have been put forth in literature as $[42,45]$ :

a) The cytokines might directly affect the growth and/ or virulence activity of bacterial species.

b) Indirect mechanism considers that an increased inflammatory response to a given microbial challenge occurs due to an over-production of cytokines. An increased gingival crevice fluid flow in response to inflammation might foster increased levels of subgingival species, particularly species of the red and orange complexes. So, increased levels of these species in turn may affect the local tissues leading to increased inflammation and pocket formation. c) Both the overall lower serum antibody levels and specific titers against selected bacteria have responsible for their colonisation.

\section{Genome wide association studies in context of periodontal Infectogenomics}

The concept of periodontal infectogenomics has been investigated in genome wide association studies (GWAS) also in addition to cross sectional or case control study designs. Among participants of the Atherosclerosis Risk in Communities (ARIC) longitudinal cohort investigation (The ARIC Investigators, 1989) did not reveal a significant genome wide signals but suggested that 13 loci, including KCNK1, FBXO38, UHRF2, IL33, RUNX2, TRPS1, CAMTA1, and VAMP3, provide an evidence of association for red and orange complex microbiota except Aggregatibacter actinomycetemcomitans [2]. These results are further carried forward in another genome association study using MAGENTA (meta-analysis gene set enrichment of variant associations) approach to obtain genecentric and gene set association results. The statistically significant association has been found for 6 genes; 4 with severe chronic periodontitis (NIN, ABHD12B, WHAMM, $A P 3 B 2)$ and 2 with high periodontal pathogen colonisation (red complex - KCNK1, Porphyromonas gingivalis $D A B 2 I P)$. The top gene sets included have been: for severe chronic periodontitis - endoplasmic reticulum membrane, cytochrome $\mathrm{P} 450$, microsome and oxidation reduction; for moderate chronic periodontitis - regulation of gene expression, zinc ion binding, BMP signalling pathway and ruffle; for periodontal pathogen colonisation-circadian clock system for red complex, $\mathrm{G}$ alpha $\mathrm{Z}$ signalling events for orange complex, KEGG mismatch repair for Aggregatibacter actinomycetemcomitans and protein binding for Porphyromonas gingivalis [25]. Thus, highlighted genes in previously identified loci and new candidate genes for explaining possible pathways associated with chronic periodontitis.

Recently genome wide association of chronic periodontitis is conducted by supplementing clinical data with biological intermediates of microbial burden and local inflammatory response with the formation of periodontal complex traits (PCTs). PCT1 has been characterised by a uniformly high pathogen load (Socransky trait), PCT4 with a mixed infection community whereas PCT3 and PCT5 have been dominated by Aggregatibacter actinomycetemcomitans and Porphyromonas gingivalis, respectively [10]. The genome-wide significant signals have been detected as mentioned in Table 1.

These highlighted loci mainly include genes associated with immune response and epithelial barrier function which enhance the disease susceptibility in the presence of a dysbiotic microbial structure [10]. However, these loci have not been associated with clinically defined disease 
Table 1 Genome wide significant signals and the closest gene associated

\begin{tabular}{|c|c|c|}
\hline Locus & SNP & Closest gene \\
\hline \multicolumn{3}{|c|}{ PCT1 (Socransky Trait) } \\
\hline $16 q 11.2$ & rs1156327 & CLEC19A (C-type lectin domain family 19 member A) \\
\hline $14 q 21$ & rs3811273 & TRA (Transfer gene) \\
\hline $12 q 14$ & rs17184007 & GGTA2P (Glycoprotein, Alpha- Galactosyltransferase 2 Pseudogene) \\
\hline $13 q 32.3$ & rs9557237 & TM9SF2 (Transmembrane 9 Superfamily Member 2) \\
\hline $1 q 12$ & rs1633266 & IFI16 (Interferon, Gamma-Inducible Protein 16) \\
\hline $3 q 12$ & rs17718700 & RBMS3 (RNA Binding Motif Single Stranded Interacting Protein 3) \\
\hline \multicolumn{3}{|c|}{ PCT3 (Aa Trait) } \\
\hline $4 p 15.33$ & rs4074082 & C1QTNF7 (C1q and tumour necrosis factor-related protein 7) \\
\hline $8 q 24.3$ & rs9772881 & TSNARE (T-SNARE Domain Containing) \\
\hline \multicolumn{3}{|c|}{ PCT4 (Mixed Infection) } \\
\hline $7 q 21.1$ & rs10232172 & HPVC1 (Human Papillomavirus (type 18) E5 Central Sequence Like 1) \\
\hline \multicolumn{3}{|c|}{ PCT5(Pg Trait) } \\
\hline $12 q 14$ & rs7135417 & SLC15A4 (Solute Carrier Family 15 Member 4) \\
\hline $11 q 14$ & rs6488099 & PKP2 (plakophilin 2) \\
\hline $15 q 24$ & Rs904310 & SNRPN (Small Nuclear Ribonucleoprotein Polypeptide N) \\
\hline
\end{tabular}

which raises the possibility that these PCTs may be genetically tractable endophenotypes that nevertheless have little relevance to disease defined with clinical criteria alone. This has been suggested that the six PCTs, although having overlapping clinical presentations, may actually reflect six different conditions with distinct genetic risk profiles that may be discoverable only in the context of specific patterns of microbial dysbiosis and inflammatory response [10]. These new findings provide a logical sub-classification of disease based upon genetic and microbial-inflammatory signatures that warrants further validation.

Recently, a systematic review has been conducted on the periodontal infectogenomics included a total of 43 studies consisted of candidate genes and the above mentioned genome wide analyses and given a conclusion that there is no evidence yet that neither IL- 1 genetic polymorphisms nor any other investigated genetic polymorphisms are associated with presence and counts of subgingival microbiota. This is because of the heterogeneity and complexity of the study, case control study approach, small sample sizes and risk of bias analysis [80].

\section{Summary}

To summarise, the host genotype may affect the colonisation pattern of subgingival species has been extensively discussed in the past few years. Nibali L et al. have reported that IL-6 hyperproducers (IL-6-174GG genotype subjects) show consistent association with Aggregatibacter actinomycetemcomitans detection in several independent studies in different populations. However, majority of the investigations of IL-1 and TNF- $\alpha$ polymorphisms have primarily reported association with subgingival colonisation of red and orange complex bacteria, but failed to give conclusive statements due to heterogeneity. The haplotypes of IL-4, IL-8 and IL-10 polymorphisms also has been associated with microbial colonisation. Other investigations about candidate genes vis IL-2, IL-12, IFN- $\gamma$, HLA class II, NF- $\kappa \beta$, vitamin D receptor, MMP8, T-bet, apolipoprotein E and PPAR $\gamma$ polymorphisms had not documented any significant association with the pathogen colonisation. The findings from the published literature emphasises that in IL- 2 , IFN- $\gamma$, HLA class II and NF- $\kappa \beta$ genotype needs further exploration of this association. Specifically, genotypes affecting pathogen detection receptors viz. CD14 $260 \mathrm{CT}+\mathrm{TT}$ genotype has showed association with the red complex bacterias. MBL2 homozygote variant is found to be the only studied complement component suggesting the possibility to provoke the virulence of A. actinomycetemcomitans and $\mathrm{F}_{\mathrm{C} \gamma}$ receptors reported the hyperactive phenotype of PMNs affecting the PMN function mainly phagocytosis and oxidative burst, resulting in severe microbial effect on periodontal tissue. Some of the polymorphisms associated with enhancement in special periodontal conditions as in case of gingival overgrowth subjects, the CD14 260 and IL-10 haplotype have been associated with the microbial colonisation of red complex bacteria. Since GWAS have been recently introduced in study of Periodontology, the evidence needs further exploration to define some conclusive association. So, the contemporary evidence available to explain the concept of periodontal imfectogenomics is complied as shown in Table 2. 


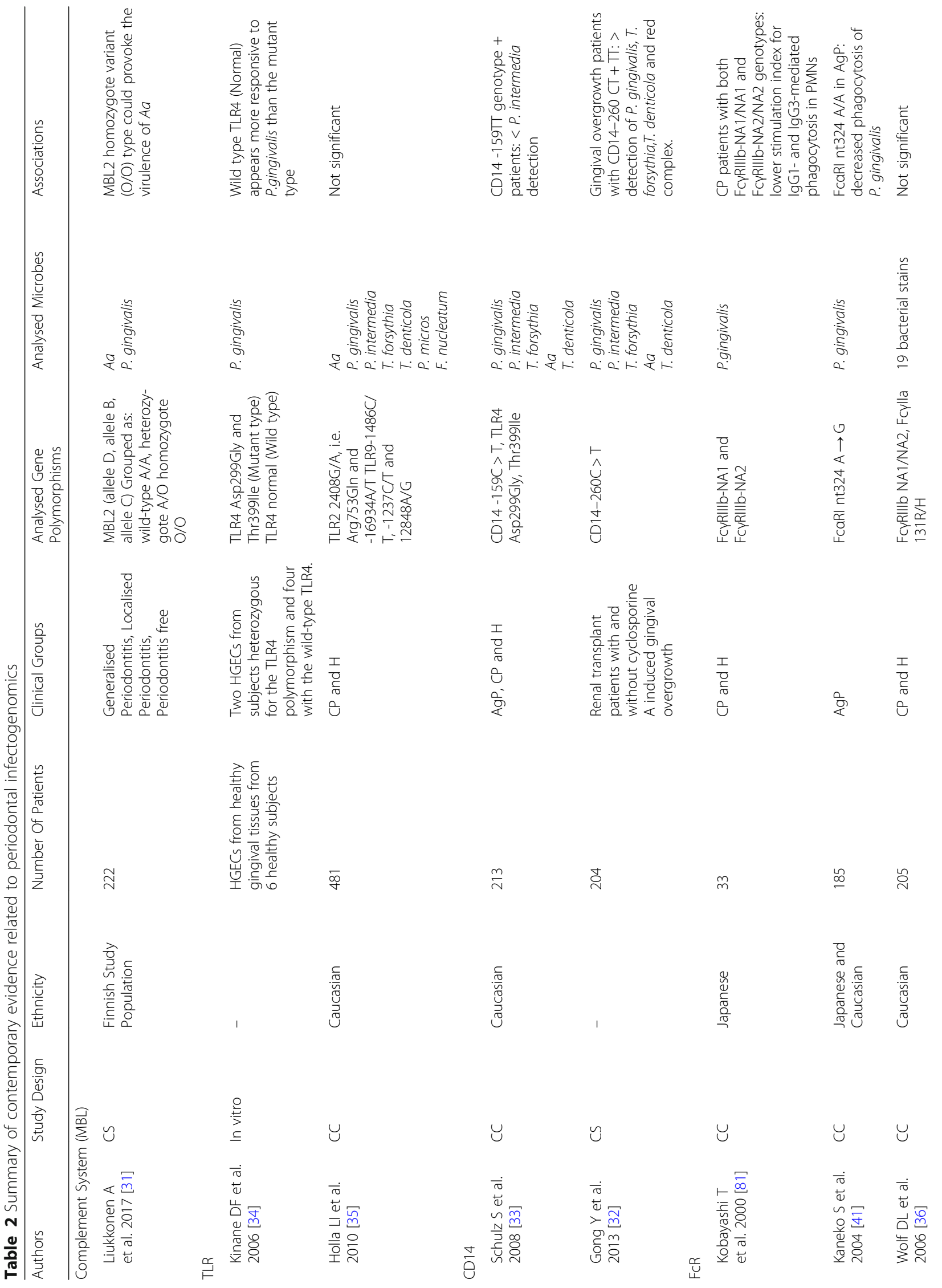




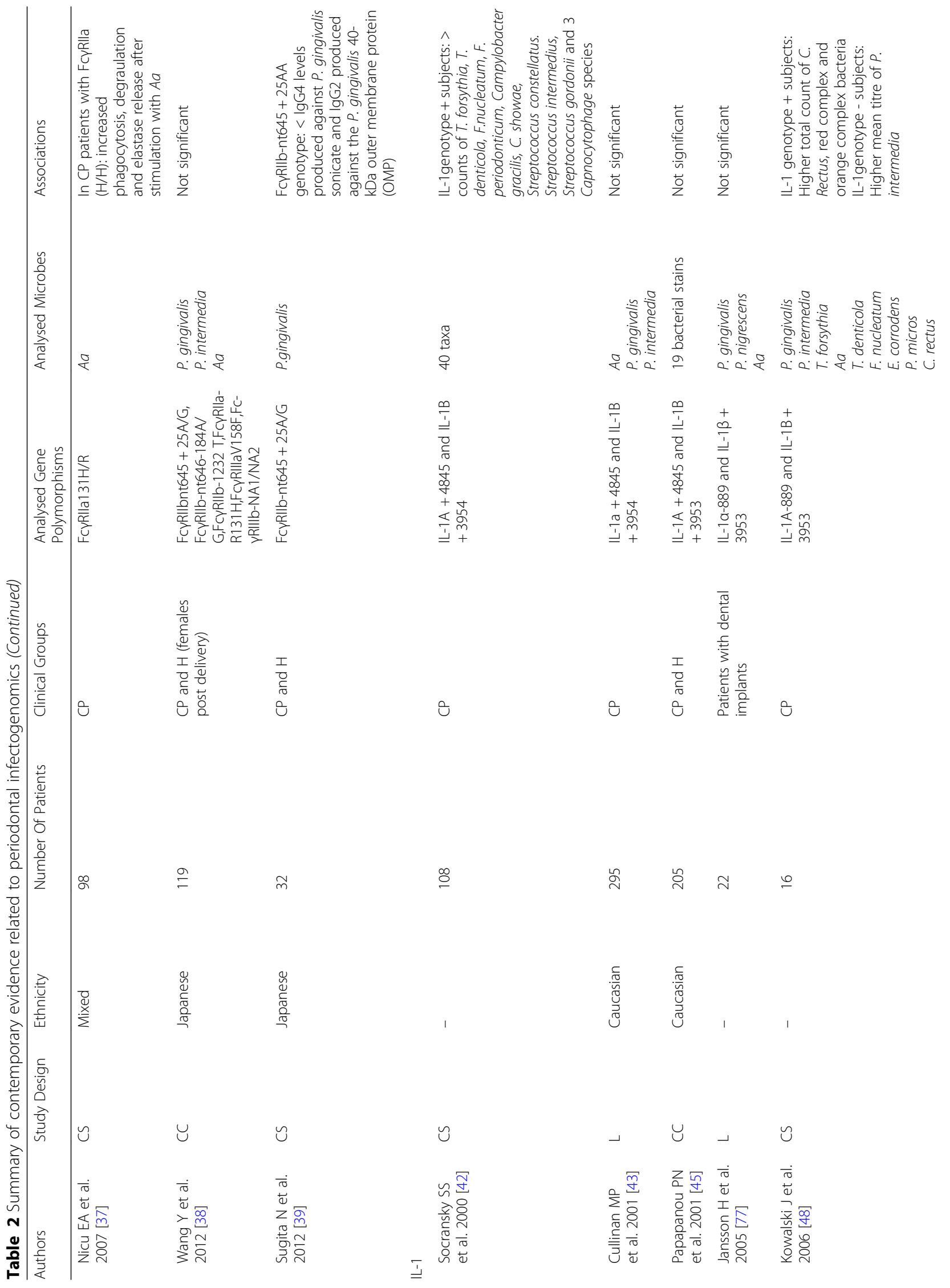




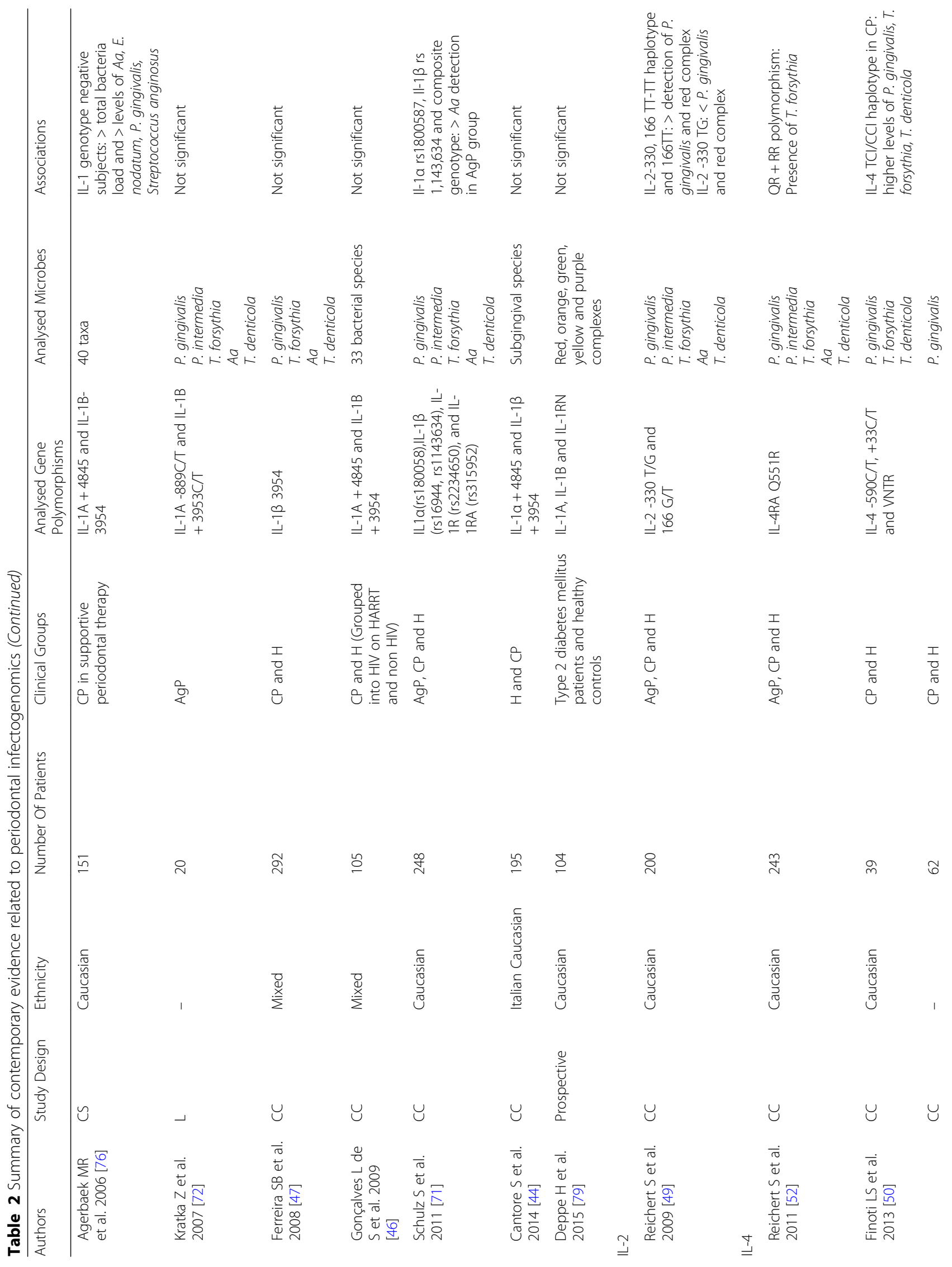


Gaur et al. Inflammation and Regeneration (2018) 38:8

Page 11 of 17

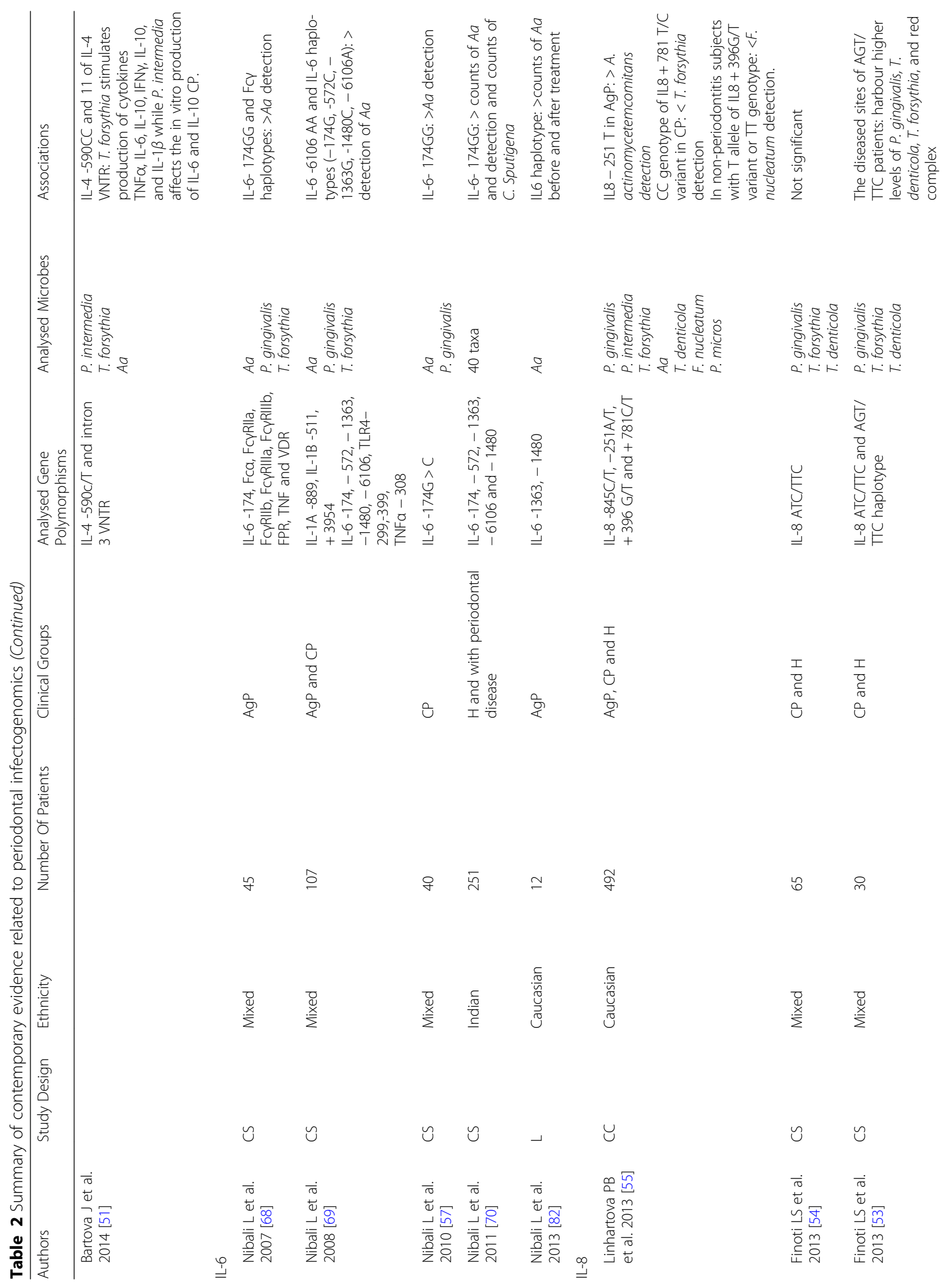


Gaur et al. Inflammation and Regeneration (2018) 38:8

Page 12 of 17

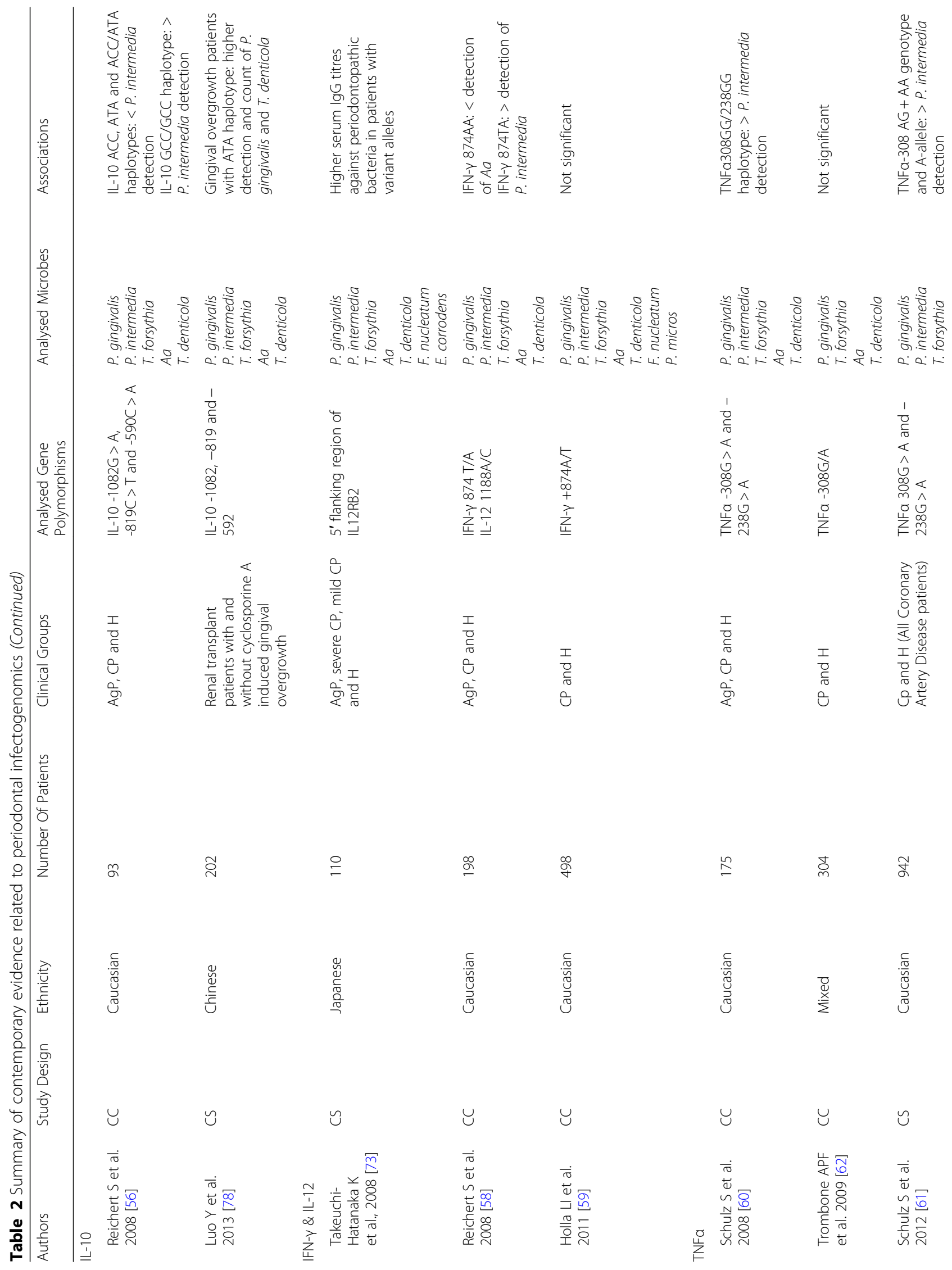


Kaur et al. Inflammation and Regeneration (2018) 38:8

Page 13 of 17

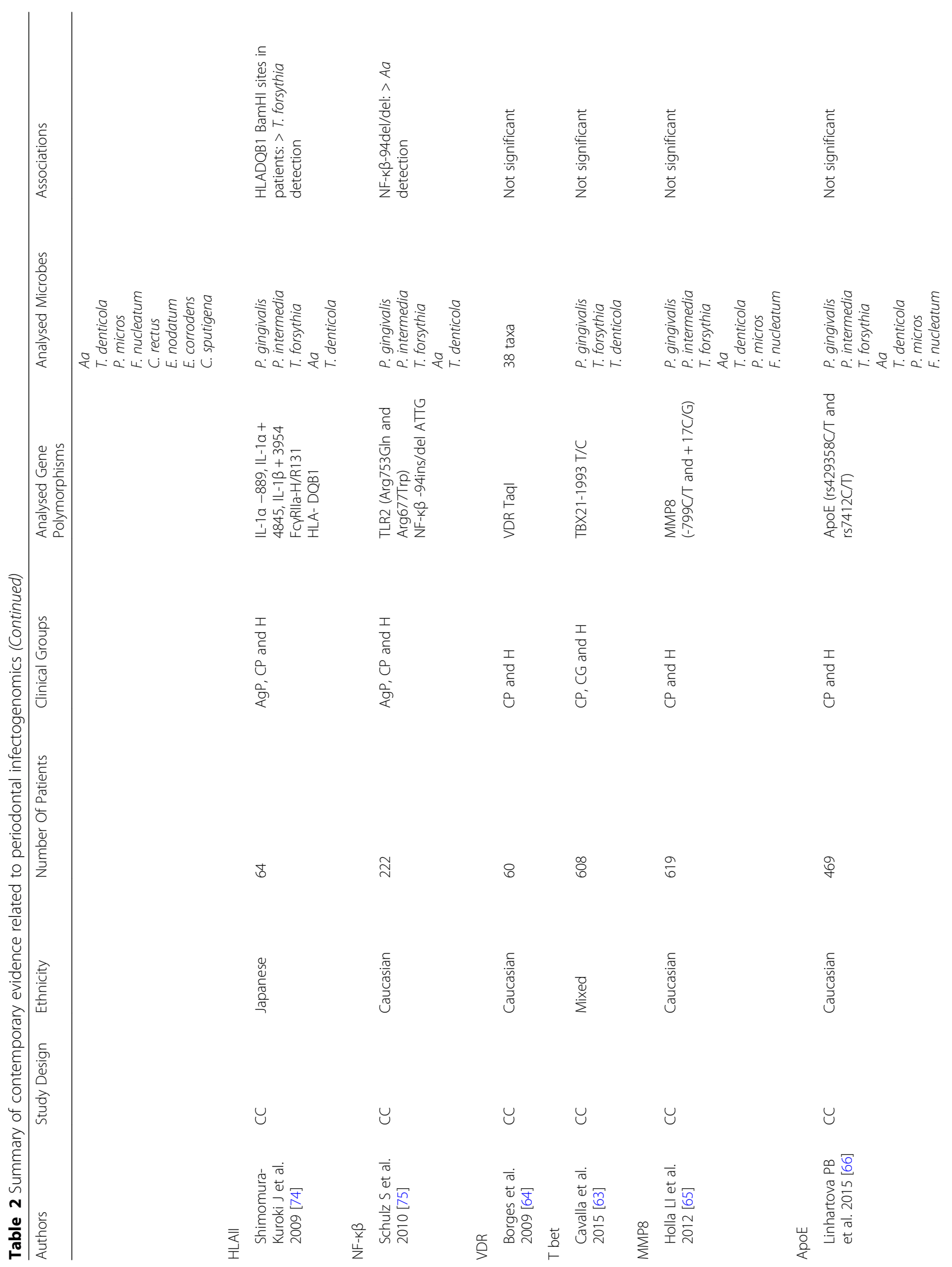




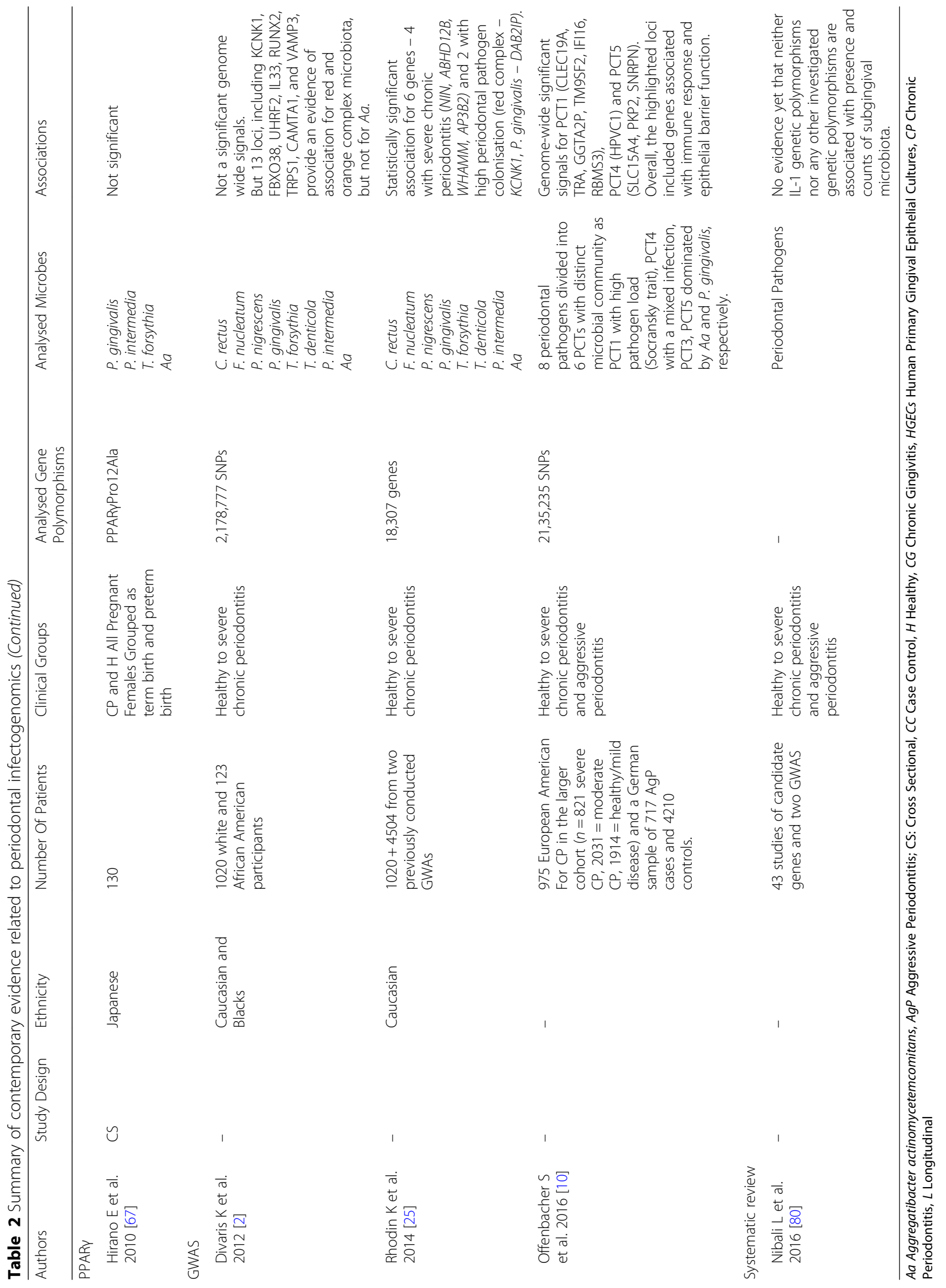


The major issues concerned to the study of infectogenomics is the difficulty in comprehensively examining the subgingival microbiota which is further complicated by nature of microbial infection, biofilm type formed where both the symbiotic and exogenous bacteria are organised which behave as part of a complex and polymicrobial nature of periodontal infection and due to inadequate knowledge of specific host genetic factors that are likely to affect the subgingival microbiota.

\section{Conclusion}

The functional genomics of host has crucial importance while analysing host- pathogen interactions in the pathogenesis of periodontal disease. An increased understanding of the genetics underpinning of interactions between the host and exogenous or symbiotic bacterial communities has the potential to advance our knowledge not only of periodontitis, but also of other chronic inflammatory and microbiome-related diseases. Several risk loci identified may offer promising leads for further exploration and mechanistic studies which have the potential to unveil pathways and mechanisms that direct the host's symbiosis with healthy microflora to dysbiosis state which may predispose to the disease state. Therefore, infectogenomics may serve as a useful model to study the relationship between host genome and microbial challenge. Further exploration of the concept is essential to identify infectious states, to understand the host response, to predict disease outcomes, to monitor responses to antimicrobial therapies and to indicate promising new types of treatment.

\section{Future directions}

The field of periodontal infectogenomics can determine different pathogenic pathways in different forms of periodontitis, and possibly assist in early prevention and management of disease. Additional multicentre studies based on large population samples in different populations and with high-quality phenotypes need to be conducted worldwide to identify the human genetic factors that predispose to invasion by pathogens and to their proliferation. Changes in gene expression profiles can also determine the type of pathogen present. Thus, gene expression patterns in the blood could serve as a window into the pathogenesis and diagnosis of infectious diseases. Advances in gene expression profiling may possibly provide the chance for adjunctive pharmacological treatment. Further research is needed to validate the biologic basis for genetic susceptibility testing, to evaluate the ability of different genotypes to predict disease initiation and to evaluate the effectiveness of genotyping in making diagnostic or treatment intervention strategies, especially in dental new age tissue engineering approach. However, the consideration of specific microbiota with distinct exposure is consistent with the paradigm of periodontal medicine which may provide an insight into the new alternative connection of oral-systemic diseases.

\begin{abstract}
Abbreviations
Aa: Aggregatibacter actinomycetemcomitans; ABHD12B: Abhydrolase Domain Containing 12B; AgP: Aggressive Periodontitis; AP3B2: Adapter Related Protein Complex 3 Beta 2 Subunit; BMP: Bone Morphogenetic Protein; CC: Case Control; CCR5: Chemokine Receptor 5; CG: Chronic Gingivitis; CP: Chronic Periodontitis; CS: Cross Sectional; DAB2IP: Disabled Homolog 2 Interacting Protein; H: Healthy; HGECs: Human Primary Gingival Epithelial Cultures; HIV: Human Immunodeficiency Virus; HLA: Human Leukocyte Antigen; IFN-ү: Interferon Gamma; IL-4RA: Interleukin -4 Receptor a Chain 43; KCNK1: Potassium Two Pore Domain Channel Subfamily K Member 1; L: Longitudinal.; MBL: Mannose Binding Ligand; MHC II: Major Histocompatibility Complex II; MMP 8: Matrix Metalloproteinases 8; NFk $\beta$ : Nuclear Factor Kappa $\beta$; PAMPs: Pathogen Associated Molecular Patterns; PRPs: Peptidoglycan Recognition Proteins; RUNX2: Runt Related Transcription Factor 2; SNPs: Single Nucleotide Polymorphisms; Th: T Helper Cells; TNF-

a: Tumor Necrosis Factor Alpha; TRPS1: Transcription Repressor GATA Binding 1; UHRF2: Ubiquitin like PHD and Ring Finger Domain 2; VAMP3: Vesicle associated Membrane Protein 3; WHAMM: WAS Protein Homolog Associated with Actin, Golgi Membranes and Microtubules
\end{abstract}

\section{Acknowledgements}

We would like to express our sincere gratitude to all the authors for contributing to the review cited in the present manuscript.

Funding

Not applicable.

\section{Availability of data and materials \\ Not applicable.}

\section{Authors' contributions}

All authors contributed equally to drafting the manuscript. All authors read, revised, and approved the final manuscript.

Ethics approval and consent to participate Not applicable.

Consent for publication

Not applicable.

Competing interests

The authors declare that they have no competing interests.

\section{Publisher's Note}

Springer Nature remains neutral with regard to jurisdictional claims in published maps and institutional affiliations.

Received: 11 December 2017 Accepted: 27 March 2018 Published online: 07 May 2018

\section{References}

1. Laddha R, Sehdev B, Saini NK, Zubedi T, Narang AK. Periodontal Infectogenomics: a review. Int J Dent Med Res. 2015;1(6):189-92.

2. Divaris $K$, Monda KL, North KE, Olshan AF, Lange EM, Moss K, et al. Genomewide association study of periodontal pathogen colonization. J Dent Res. 2012;91(Suppl 7):21S-8S.

3. Nibali L, Donos N, Henderson B. Periodontal Infectogenomics. J Med Microbiol. 2009:58:1269-74.

4. Laine ML, Loos BG, Crielaard W. Gene polymorphisms in chronic periodontitis. Int J Dent. 2010;2010:324719.

5. Hart TC, Korman KS. Genetic factors in the pathogenesis of periodontitis. Periodontol. 1997;14:202-15.

6. Kinane DF, Shiba H, Hart TC. The genetic basis of periodontitis. Periodontol 2000. 2005;39:91-117.

7. Takashiba S, Naruishi K. Gene polymorphisms in periodontal health and disease. Periodontol 2000. 2006;40:94-106. 
8. Nasry B, Choong C, Flamiatos E, Chai J, Kim N, Strauss S, et al. Diversity of the oral microbiome and dental health and disease. Int I Clin Med Microbiol. 2016;1:108.

9. Nibali L, Henderson B, Sadiq ST, Donos N. Genetic dysbiosis: the role of microbial insults in chronic inflammatory diseases. J Oral Microbiol. 2014; 25(6):22962.

10. Offenbacher S, Divaris K, Barros SP, Moss KL, Marchesan JT, Morelli T, Zhang S, Kim S, Sun L, Beck JD, Laudes M, Munz M, Schaefer AS, North KE. Genome-wide association study of biologically informed periodontal complex traits offers novel insights into the genetic basis of periodontal disease. Hum Mol Genet. 2016;25(10):2113-29.

11. Kellam P, Weiss RA. Infectogenomics: insights from the host genome into infectious diseases. Cell. 2006;124(4):695-7.

12. Hill AV. The genomics and genetics of human infectious disease susceptibility. Annu Rev Genomics Hum Genet. 2001;2:373-400.

13. Weatherall DJ, Clegg JB. Genetic variability in response to infection: malaria and after. Genes Immun. 2002;3(6):331-7.

14. Blekhman R, Goodrich JK, Huang K, Sun Q, Bukowski R, Spector D, et al. Host genetic variation impacts microbiome composition across human body sites. Genome Biol. 2015;16:191-201.

15. Gasche C, Nemeth M, Grundtner P, Willheim-Polli C, Ferenci P, Schwarznbacher R. Evolution of crohn's disease- associated Nod2 mutations. Immunogenetics. 2008;60(2):115-20.

16. de Silva E, Stumpf MP. HIV and the CCR5- $\triangle 32$ resistance allele. FEMS Microbiol Lett. 2004;241(1):1-12.

17. Galvani AP, Slatkin M. Evaluating plague and smallpox as historical selective pressures for the CCR5- $\triangle 32$ HIV-resistance allele. Proc Natl Acad Sci U S A. 2003;100(25):15276-9.

18. Taborda-Vanegas N, Zapata W, Rugeles MT. Genetic and immunological factors involved in natural resistance to HIV-1 infection. Open Virol J. 2011;5:35-43.

19. Kwiatkowski D. Genetic susceptibility to malaria getting complex. Curr Opin Genet Dev. 2000;10(3):320-4.

20. Drumm ML, Ziady AG, Davis PB. Genetic variation and clinical heterogeneity in cystic fibrosis. Annu Rev Pathol. 2012;7:267-82.

21. Campodónico VL, Gadjeva M, Paradis-Bleau C, Uluer A, Pier GB. Airway epithelial control of Pseudomonas aeruginosa infection in cystic fibrosis. Trends Mol Med. 2008;14(3):120-33.

22. Fernando SL, Britton WJ. Genetic susceptibility to mycobacterial disease in humans. Immunol Cell Biol. 2006;84(2):125-37.

23. Thursz M. Genetic susceptibility in chronic viral hepatitis. Antivir Res. 2001; 52(2):113-6.

24. Knights $D$, Lassen $K G$, Xavier RJ. Advances in inflammatory bowel disease pathogenesis: linking host genetics and the microbiome. Gut. 2013;62(10): 1505-10.

25. Rhodin K, Divaris K, North KE, Barros SP, Moss K, Beck JD, Offenbacher S. Chronic periodontitis genome wide association studies: gene centric and gene set enrichment analyses. J Dent Res. 2014;93(9):882-90.

26. Hajishengallis G, Maekawa T, Abe T, Hajishengallis E, Lambris JD. Complement involvement in periodontitis: molecular mechanisms and rational therapeutic approaches. Adv Exp Med Biol. 2015:865:57-74.

27. Hajishengallis G, Abe T, Maekawa T, Hajishengallis E, Lambris JD. Role of complement in host-microbe homeostasis of the periodontium. Semin Immunol. 2013;25:65-72.

28. Marianne R, Nikolaus R, Matthias $\mathrm{S}$, et al. Periodontal Ehlers-Danlos syndrome is caused by mutations in C1R and C1S, which encode subcomponents $\mathrm{C} 1 \mathrm{r}$ and C1s of complement. Am J Hum Genet. 2016:99(5):1005-14.

29. Zhan $Y$, Zhang $R, L v H$, Song $X$, Xu X, Chai L, Lv W, Shang Z, Jiang Y, Zhang R. Prioritization of candidate genes for periodontitis using multiple computational tools. J Periodontol. 2014;85:1059-69.

30. Chai L, Song $Y-Q$, Zee K-Y, Leung WK. Single nucleotide polymorphisms of complement component 5 and periodontitis. J Periodont Res. 2010;45:301-8.

31. Liukkonen A, He Q, Gürsoy UK, Pussinen PJ, Gröndahl-Yli-Hannuksela K, Liukkonen J, Sorsa T, Suominen AL, Huumonen S, Könönen E. Mannosebinding lectin gene polymorphism in relation to periodontal infection. J Periodont Res. 2017:52:540-5.

32. Gong Y, Bi W, Cao L, Yang Y, Chen J, Yu Y. Association of CD14-260 polymorphisms, red-complex periodontopathogens and gingival crevicular fluid cytokine levels with cyclosporine A-induced gingival overgrowth in renal transplant patients. J Periodontal Res. 2013;48(2):203-12.

33. Schulz S, Zissler N, Altermann W, Klapproth J, Zimmermann U, Gläser C, et al. Impact of genetic variants of CD14 and TLR4 on subgingival periodontopathogens. Int J Immunogenet. 2008;35(6):457-64.
34. Kinane DF, Shiba H, Stathopoulou PG, Zhao H, Lappin DF, Singh A, et al. Gingival epithelial cells heterozygous for toll-like receptor 4 polymorphisms Asp299Gly and Thr399lle are hypo-responsive to Porphyromonas gingivalis. Genes Immun. 2006:7(3):190-200.

35. Holla LI, Vokurka J, Hrdlickova B, Augustin P, Fassmann A. Association of Toll-like receptor 9 haplotypes with chronic periodontitis in Czech population. J Clin Periodontol. 2010;37(2):152-9.

36. Wolf DL, Neiderud AM, Hinckley K, Dahlén G, van de Winkel JG, Papapanou PN. Fcy receptor polymorphisms and periodontal status: a prospective follow-up study. J Clin Periodontol. 2006;33(10):691-8.

37. Nicu EA, Van der Velden U, Everts V, Van Winkelhoff AJ, Roos D, Loos BG. Hyperreactive PMNs in FcyRlla $131 \mathrm{H} / \mathrm{H}$ genotype periodontitis patients. J Clin Periodontol. 2007;34(1):938-45.

38. Wang Y, Sugita N, Kikuchi A, Iwanaga R, Hirano E, Shimada Y, et al. FcyRIIBnt645+25A/G gene polymorphism and periodontitis in Japanese women with preeclampsia. Int J Immunogenet. 2012;39(6):492-500.

39. Sugita N, Iwanaga R, Kobayashi T, Yoshie H. Association of the FcyRlliBnt645 $+25 \mathrm{~A} / \mathrm{G}$ polymorphism with the expression level of the FcyRllb receptor, the antibody response to Porphyromonas gingivalis and the severity of periodontitis. J Periodontal Res. 2012;47(1):105-13.

40. Yoshie H, Kobayashi T, Tai H, Galicia JC. The role of genetic polymorphisms in periodontitis. Periodontol 2000. 2007:43:102-32.

41. Kaneko S, Kobayashi T, Yamamoto K, Jansen MD, van de Winkel JG, Yoshie H. A novel polymorphism of FcaRI (CD89) associated with aggressive periodontitis. Tissue Antigens. 2004;63(6):572-7.

42. Socransky SS, Haffajee AD, Smith C, Duff GW. Microbiological parameters associated with IL-1 gene polymorphisms in periodontitis patients. J Clin Periodontol. 2000;27(11):810-8.

43. Cullinan MP, Westerman B, Hamlet SM, Palmer JE, Faddy MJ, Lang NP, Seymour GJ. A longitudinal study of interleukin-1 gene polymorphisms and periodontal disease in a general adult population. J Clin Periodontol. 2001;28(12):1137-44.

44. Cantore S, Mirgaldi R, Ballini A, Coscia MF, Scacco S, Papa F, et al. Cytokine gene polymorphisms associate with microbiological agents in periodontal disease: our experience. Int J Med Sci. 2014;11(7):674-9.

45. Papapanou PN, Neiderud AM, Sandros J, Dahlén G. Interleukin-1 gene polymorphism and periodontal status. A case-control study. J Clin Periodontol. 2001;28(5):389-96.

46. Gonçalves LS, Ferreira SM, Souza CO, Colombo AP. Influence of IL-1 gene polymorphism on the periodontal microbiota of HIV infected Brazilian individuals. Braz Oral Res. 2009;23(4):452-9.

47. Ferreira SB Jr, Trombone AP, Repeke CE, Cardoso CR, Jr MW, Santos CF, et al. An interleukin-1 $\beta$ single nucleotide polymorphism at position 3954 and red complex periodontopathogens independently and additively modulate the levels of IL-1 $\beta$ in diseased periodontal tissues. Infect Immun. 2008;76(8):3725-34.

48. Kowalski J, Górska R, Dragan M, Kozak I. Clinical state of the patients with periodontitis, IL-1 polymorphism and pathogens in periodontal pocket - is there a link? (an introductory report). Adv Med Sci. 2006;51(Suppl 1):9-12.

49. Reichert S, Machulla HK, Klapproth J, Zimmermann U, Reichert Y, Gläser C, et al. Interleukin-2 -330 and 166 gene polymorphisms in relation to aggressive or chronic periodontitis and the presence of periodontopathic bacteria. J Periodontal Res. 2009;44(5):628-35.

50. Finoti LS, Anovazzi G, Pigossi SC, Corbi SC, Teixeira SR, Braido GV, et al. Periodontopathogens levels and clinical response to periodontal therapy in individuals with the interleukin 4 haplotype of susceptibility to chronic periodontitis. Int J Microbiol. Res Rev. 2013;1(2):039-47.

51. Bartova J, Linhartova PB, Podzimek S, Janatova T, Svobodova K, Fassmann A, et al. The effect of $\mathrm{L}-4$ gene polymorphisms on cytokine production in patients with chronic periodontitis and in healthy controls. Mediat Inflamm. 2014;2014:185757.

52. Reichert S, Stein JM, Klapproth J, Zimmermann U, Reichert Y, Gläser C, et al. The genetic impact of the Q551R interleukin-4 receptor alpha polymorphism for aggressive or chronic periodontitis and the occurrence of periodontopathic bacteria. Arch Oral Biol. 2011;56(12):1485-93.

53. Finoti LS, Corbi SC, Anovazzi G, Teixeira SR, Capela MV, Tanaka MH, et al. Pathogen levels and clinical response to periodontal treatment in patients with interleukin 8 haplotypes. Pathog Dis. 2013;69:21-8.

54. Finoti LS, Corbi SC, Anovazzi G, Teixeira SR, Steffens JP, Secolin R, et al. Association between IL8 haplotypes and pathogen levels in chronic periodontitis. Eur J Clin Microbiol Infect Dis. 2013;32(10):1333-40.

55. Barilova Linhartova P, Vokurka J, Poskerova H, Fassmann A, Izakovicova Holla L. Haplotype analysis of interleukin-8 gene polymorphisms in chronic and aggressive periodontitis. Mediat Inflamm. 2013;2013:342351. 
56. Reichert S, Machulla HK, Klapproth J, Zimmermann U, Reichert Y, Gläser CH, et al. The interleukin-10 promoter haplotype ATA is a putative risk factor for aggressive periodontitis. J Periodontal Res. 2008;43(1):40-7.

57. Nibali L, Donos N, Farrell S, Ready D, Pratten J, Tu YK, D'Aiuto F. Association between interleukin-6-174 polymorphism and Aggregatibacter actinomycetemcomitans in chronic periodontitis. J Periodontol. 2010;81(12):1814-9.

58. Reichert S, Machulla HK, Klapproth J, Zimmermann U, Reichert Y, Gläser C, et al. Interferon-gamma and interleukin-12 gene polymorphisms and their relation to aggressive and chronic periodontitis and key periodontal pathogens. J Periodontol. 2008;79(8):1434-43.

59. Holla LI, Hrdlickova B, Linhartova P, Fassmann A. Interferon- $\gamma+874 \mathrm{~A} / \mathrm{T}$ polymorphism in relation to generalized chronic periodontitis and the presence of periodontopathic bacteria. Arch Oral Biol. 2011;56(2):153-8.

60. Schulz S, Machulla HK, Altermann W, Klapproth J, Zimmermann U, Gläser C, et al. Genetic markers of tumour necrosis factor a in aggressive and chronic periodontitis. J Clin Periodontol. 2008;35(6):493-500.

61. Schulz S, Schlitt A, Lutze A, Lischewski S, Seifert T, Dudakliewa T, et al. The importance of genetic variants in TNFa for periodontal disease in a cohort of coronary patients. J Clin Periodontol. 2012;39(8):699-706.

62. Trombone AP, Cardoso CR, Repeke CE, Ferreira SB Jr, Martins W Jr, Campanelli AP, et al. Tumor necrosis factor-alpha -308G/a single nucleotide polymorphism and red-complex periodontopathogens are independently associated with increased levels of tumor necrosis factor-alpha in diseased periodontal tissues. J Periodontal Res. 2009;44(5):598-608.

63. Cavalla F, Biguetti CC, Colavite PM, Silveira EV, Jr MW, Letra A, et al. TBX211993T/C (rs4794067) polymorphism is associated with increased risk of chronic periodontitis and increased T-bet expression in periodontal lesions, but does not significantly impact the IFN- $\gamma$ transcriptional level or the pattern of periodontophatic bacterial infection. Virluence. 2015;6(3):293-304.

64. Borges MA, Figueiredo LC, Brito RB Jr, Faveri M, Feres M. Microbiological composition associated with vitamin $D$ receptor gene polymorphism in chronic periodontitis. Braz Oral Res. 2009;23(2):203-8.

65. Holla LI, Hrdlickova B, Vokurka J, Fassmann A. Matrix metalloproteinase 8 (MMP8) gene polymorphisms in chronic periodontitis. Arch Oral Biol. 2012; 57(2):188-96.

66. Borilova Linhartova P, Bartova J, Poskerova H, Machal J, Vokurka J, Fassmann A, Izakovicova Holla L. Apolipoprotein E gene polymorphisms in relation to chronic periodontitis, periodontopathic bacteria, and lipid levels. Arch Oral Biol. 2015;60(3):456-62.

67. Hirano E, Sugita N, Kikuchi A, Shimada Y, Sasahara J, Iwanaga R, et al. Peroxisome proliferator-activated receptor gamma polymorphism and periodontitis in pregnant japanese women. J Periodontol. 2010;81(6):897-906.

68. Nibali L, Ready DR, Parkar M, Brett PM, Wilson M, Tonetti MS, Griffiths GS Gene polymorphisms and the prevalence of key periodontal pathogens. J Dent Res. 2007:86(5):416-20.

69. Nibali L, Tonetti MS, Ready D, Parkar M, Brett PM, Donos N, D'Aiuto F. Interleukin-6 polymorphisms are associated with pathogenic bacteria in subjects with periodontitis. J Periodontol. 2008;79(4):677-83.

70. Nibali L, Madden I, Franch Chillida F, Heitz-Mayfield L, Brett P, Donos N. IL6174 genotype associated with Aggregatibacter actinomycetemcomitans in Indians. Oral Dis. 2011;17(2):233-7.

71. Schulz S, Stein JM, Altermann W, Klapproth J, Zimmermann U, Reichert Y, et al. Single nucleotide polymorphisms in interleukin-1gene cluster and subgingival colonization with Aggregatibacter actinomycetemcomitans in patients with aggressive periodontitis. Hum Immunol. 2011;72(10):940-6.

72. Krátká Z, Bártová J, Krejsa O, Otčenášková M, Janatová T, Dušková J. Interleukin-1 gene polymorphisms as assessed in a 10-year study of patients with early-onset periodontitis. Folia Microbiol. 2007;52(2):183-8.

73. Takeuchi-Hatanaka K, Ohyama H, Nishimura F, Kato-Kogoe N, Soga Y, Matsushita $\mathrm{S}$, et al. Polymorphisms in the $5^{\prime}$ flanking region of IL12RB2 are associated with susceptibility to periodontal diseases in the Japanese population. J Clin Periodontol. 2008;35(4):317-23.

74. Shimomura-Kuroki J, Yamashita K, Shimooka S. Tannerella forsythia and the HLA-DQB1 allele are associated with susceptibility to periodontal disease in Japanese adolescents. Odontology. 2009;97(1):32-7.

75. Schulz S, Hierse L, Altermann W, Klapproth J, Zimmermann U, Reichert Y, et al. The del/del genotype of the nuclear factor-kB -94ATTG polymorphism and its relation to aggressive periodontitis. J Periodontal Res. 2010;45(3): 396-403.
76. Agerbaek MR, Lang NP, Persson GR. Microbiological composition associated with interleukin-1 gene polymorphism in subjects undergoing supportive periodontal therapy. J Periodontol. 2006;77(8):1397-402.

77. Jansson H, Hamberg K, De Bruyn H, Bratthall G. Clinical consequences of IL1 genotype on early implant failures in patients under periodontal maintenance. Clin Implant Dent Relat Res. 2005;7(1):51-9.

78. Luo Y, Gong Y, Yu Y. Interleukin-10 gene promoter polymorphisms are associated with cyclosporin A-induced gingival overgrowth in renal transplant patients. Arch Oral Biol. 2013;58(9):1199-207.

79. Deppe H, Mücke T, Wagenpfeil S, Kesting M, Karl J, Noe S, Sculean A. Are selected IL-1 polymorphisms and selected subgingival microorganisms significantly associated to periodontitis in type 2 diabetes patients? A clinical study. BMC Oral Health. 2015;15(1):143-50.

80. Nibali L, Di lorio A, Onabolu O, Lin GH. Periodontal infectogenomics: systematic review of associations between host genetic variants and subgingival microbial detection. J Clin Periodontol. 2016;43(11):889-900.

81. Kobayashi T, van der Pol WL, van de Winkel JG, Hara K, Sugita N, Westerdaal NA, Yoshie H, Horigome T. Relevance of IgG receptor IIIb (CD16) polymorphism to handling of Porphyromonas gingivalis: implications for the pathogenesis of adult periodontitis. J Periodontal Res. 2000;35(2):65-73.

82. Nibali L, Pelekos G, D'Aiuto F, Chaudhary N, Habeeb R, Ready D, et al. Influence of IL-6 haplotypes on clinical and inflammatory response in aggressive periodontitis. Clin Oral Investig. 2013;17(4):1235-42.

\section{Submit your next manuscript to BioMed Central and we will help you at every step:}

- We accept pre-submission inquiries

- Our selector tool helps you to find the most relevant journal

- We provide round the clock customer support

- Convenient online submission

- Thorough peer review

- Inclusion in PubMed and all major indexing services

- Maximum visibility for your research

Submit your manuscript at www.biomedcentral.com/submit
) Biomed Central 